[Agr. Biol. Chem., Vol. 28, No. 11, p. 770 773, 1964]

\title{
Acid Protease Produced by Trametes sanguinea, a Wood-destroying Fungus
}

\section{Part I. Purification and Crystallization of the Enzyme}

\author{
By Katsumi Tomoda and Hirao Shrmazono \\ Research Laboratories, Takeda Chemical Industries, Ltd. \\ Received May 29, 1964
}

\begin{abstract}
A wood-destroying fungus, Trametes sanguinea, produced a potent acid protease in a submerged culture. Maximum proteolytic activity of the culture was attained after 140-hours cultivation in a medium containing dextrin and corn steep liquor. The acid protease was obtained in crystalline form from the mycelium-free culture filtrate by the following successive treatments: acetone precipitation, ionexchange column chromatography, ammonium sulfate fractionation, dialysis, and crystallization by acetone. Throughout the over-all process, the acid protease was purified approximately 30 -fold with about $8 \%$ recovery of the original activity.
\end{abstract}

\section{INTRODUCTION}

Up to the present many reports on proteolytic enzymes in microorganisms have appeared. In Japan, proteases produced by Aspergillus, ${ }^{1,2)}$ Streptomyces, ${ }^{3)}$ Bacillus, ${ }^{4,5)}$ and Pseudomonas ${ }^{6}$ have been obtained as crystals and exhaustively examined in their enzymological natures. However, there have so far been no enzymological studies on protease produced by wood-destroying fungi. In the course of the investigation on the distribution of hydrolytic enzyme-forming organisms in wood-destroying fungi, Trametes sanguinea was found to produce a potent extracellular protease which exhibits its optimal activity in acid pII. The purpose of the present study was to develop purification and crystallization methods of the acid protease produced by Trametes sanguinea.

1) F. Yoshida, This Journal, 20, 252 (1956)

2) K. Matsushima, J. Agr. Chem. Soc. Japan, 32, 215 (1958).

3) M. Nomoto and Y. Narahashi, J. Biochem., 46, 653 (1959).

4) I. Fukumoto and H. Negoro, Symposia on Enzyme Chem. Japan, 7. $8(1952)$.

5) B. Hagihara, et al., J. Biochem, 45, 185 (1958).

6) K. Morihara, This Journal, 21, 11 (1957).

\section{EXPERIMENTAL}

\section{Organism.}

Trametes sanguinea IFO 7045 was received from the Institute for Fermentation, Osaka, Japan and used throughout the study. The stock cultures were maintained on corn steep liquor-glucose agar slants and transferred at intervals of 3 or 4 months. For experimental work, the organism was cultivated aerobically in 30-liters of a liquid medium. containing $2 \%$ corn steep liquor, $5 \%$ dextrin, $0.05 \%$ $\mathrm{MgSO}_{4} \cdot 7 \mathrm{H}_{2} \mathrm{O}$, and $0.2 \mathrm{mg} \%$ thiamine $\mathrm{HCl}$, the $\mathrm{pH}$ being adjusted to 3.0 in a 50 -liter fermenter. During cultivation the culture was maintained at 28 to $30^{\circ} \mathrm{C}$, aerated at the flow rate of 15 liters per minute, and occasionally soy bean oil was added as an antifoaming agent.

\section{Assay of Protease Activity.}

Protease activity was assayed by Kunitz's ${ }^{7}$ method with a slight modification. To $1 \mathrm{ml}$ of an enzyme solution in a test tube, equilibrated at $37^{\circ} \mathrm{C}$, was added $1 \mathrm{ml}$ of $2 \%$ casein (Hammarsten) in $0.05 \mathrm{M}$ lactate buffer ( $\mathrm{pH} 2.8$ ). After a 20 minute digestion, $3 \mathrm{ml}$ of $5 \%$ trichloroacetic acid (TCA) solution was added and incubation was continued for additional 30 minutes. The precipitated protein was removed by filtration and absorbance of the clear filtrate was read at $275 \mathrm{~m}_{\mu}$ against a blank. The blank was prepared by first mixing $1 \mathrm{ml}$ of enzyme solu-

7) M. Kunitz, J. Gen. Physiol, 30, 291 (1947). 


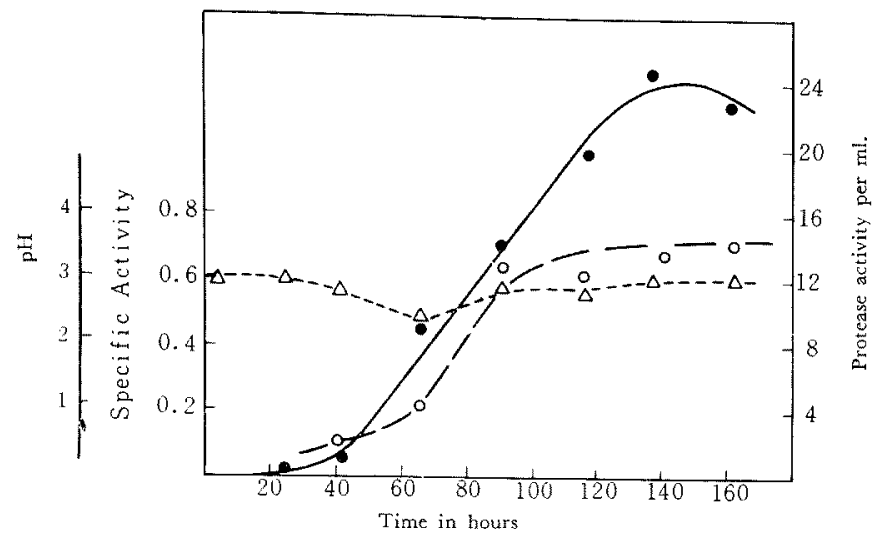

FIG. 1. Acid Protease Production by Trametes sanguinea in Submerged Cultivation.

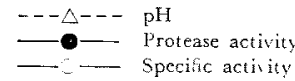

tion with $3 \mathrm{ml}$ of TCA solution, and then adding $1 \mathrm{ml}$ of casein solution. Determination of protein was carried out by a spectrophotometric method. ${ }^{8}$ Protease activity was expressed as absorbance at $275 \mathrm{~m} \mu$ directly and specific activity was expressed in terms of the activity per $\mathrm{mg}$ of protein. One unit of enzyme was defined as that amount producing $1 \mathrm{mg}$ equivalent tyrosine per minute.

\section{RESULTS AND DISCUSSION}

\section{Preparation of Crude Enzyme.}

In a submerged culture of Trametes sanguinea, as indicated in Fig. 1, maximum proteolytic activity of the culture was attained after 140 hours' cultivation. For purification studies of the acid protease, therefore, a mycelium-free filtrate obtained from the 140 hours' culture was used as starting material.

In the first step of the purification, several enzyme precipitation methods were examined to recover the crude enzyme in good yields. Addition of ammonium sulfate to the filtrate led the enzyme to a precipitate, nevertheless, the recovery did not exceed $30 \%$ of the original activity even when the filtrate was fully saturated with the sulfate.

Organic solvents were also applied for precipitating the enzyme from the filtrate. When methanol, ethanol, and acetone were added to the filtrate to a concentration of $70 \%$, recoveries

8) H. Kalckar f. Biol. Chem+, 167, 291 (1947). of the precipitated enzyme were 30, 50, and $60 \%$, respectively. Further addition of these solvents to over $80 \%$, however, did not increase the yields.

Other precipitants such as ribanol and tannic acid were all ineffective for precipitating the enzyme.

From these results, a reliable method for precipitating the enzyme from the filtrate was set up as follows: To a culture filtrate, equilibrated at 0 to $3^{\circ} \mathrm{C}$, cold acetone is added dropwise with continuous mechanical stirring to a final concentration of $70 \%$. After being left standing overnight in the cold, the precipitate is collected by centrifugation, washed once with cold acetone and dried in vacuo to give the crude enzyme powder.

\section{Ion-Exchange Resin Chromatography.}

It was found that the acid protease was adsorbed on the ion-exchange resin, Duolite CS101, which was previously washed with $0.02 \mathrm{M}$ hydrochloric acid-sodium acetate buffer $(\mathrm{pH} 3.5$ ) and, in turn, the adsorbed enzyme was eluted with $0.5 \mathrm{~m}$ hydrochloric acid-sodium acetate buffer ( $\mathrm{pH}$ 5.5). In practice, $2 \mathrm{~g}$ of the crude enzyme powder dissolved in $100 \mathrm{ml}$ of the $0.02 \mathrm{M}$ buffer $(\mathrm{pH} 3.5)$ was fed into a column $(1.6 \times 17 \mathrm{~cm})$ containing $30 \mathrm{ml}$ of the buffered resin (50 to 100 mesh), and developed first with $400 \mathrm{ml}$ of the 


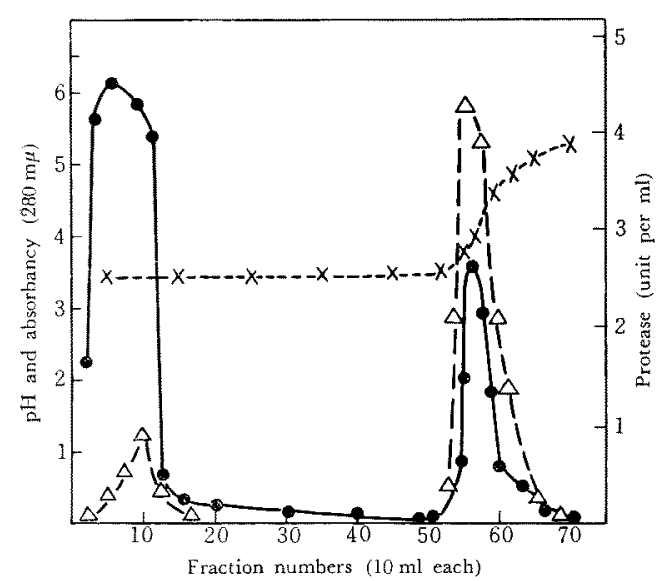

FIG. 2. Fractionation of Acid protease by IonExchange Column Chromatography. -

$0.02 \mathrm{M}$ buffer $(\mathrm{pH} 3.5)$ and then with $200 \mathrm{ml}$ of the $0.5 \mathrm{~m}$ buffer ( $\mathrm{pH} 5.5$ ). The effluent from the column was fractionated in $10 \mathrm{ml}$-portions by a fraction collector, and the enzyme rich fractions (Fraction No. 54 to 65) were mixed together to make a pool. A typical pattern of fractionation, illustrated in Fig. 2, indicates the complete resolution of the acid protease from other proteins. At this stage of purification, usually 90 to $95 \%$ of the enzyme activity was recovered and the specific activity was increased approximately 7 -fold. It was found, incidentally, that Amberlite IRC-50 could also be used as a resin bed instead of Duolite CS-101.

\section{Ammonium Sulfate Fractionation.}

This step did not cause any substantial increase in specific activity but was useful for concentrating the enzyme. To the pool of the enzyme rich fractions was added solid ammonium sulfate to 0.4 saturation, and the precipitate was removed by centrifugation and was discarded. The precipitate, obtained by adding ammonium sulfate to the supernatant solution to 0.8 saturation, was then collected by centrifugation. Recovery of the enzyme activity at this stage was usually 60 to $65 \%$.

\section{Dialysis.}

The ammonium sulfate precipitate was dissolved in $0.02 \mathrm{M}$ hydrochloric acid-sodium acetate buffer ( $\mathrm{pH} 3.5$ ) and then subjected to dialysis against the same buffer for 2 to 3 days at about $5^{\circ} \mathrm{C}$ by using a fish skin bag as a membrane of dialysis. In the course of dialysis, the buffer was continuously stirred and renewed several times to improve the efficiency of dialysis. Loss of enzyme activity at this stage was negligible.

\section{Decolorization.}

When a dark brown colored filtrate was used as starting material for purification, the enzyme was sometimes accompanied with colored impurities even after the process of dialysis. Such an enzyme solution, therefore, should be decolorized prior to enzyme crystallization. This was achieved by passing the dialyzed solution through a column containing the ion-exchange resin, Duolite A-7, without any loss of enzyme activity.

\section{Crystallization}

(a) Crystallization by acetone. The decolorized enzyme solution was diluted with $0.02 \mathrm{M}$ hydrochloric acid-sodium acetate buffer ( $\mathrm{pH} 3.5$ ) to a final protein content of $3 \%$ and was chilled to about $0^{\circ} \mathrm{C}$. To this solution was gradually added chilled acetone $\left(-10^{\circ} \mathrm{C}\right)$ with gentle agitation and the mixture was left standing in the cold. Crystallization of the enzyme was started within 24 hours and completed after 4 or 5 days' standing in a refrigerator. Recovery of the enzyme activity at this stage was about $24 \%$.

(b) Crystallization by dialysis. When the ammonium sulfate precipitate was substantially colorless, the following method was applied for the preparation of the crystalline enzyme. The ammonium sulfate precipitate was dissolved in a minimum amount of the $0.02 \mathrm{M}$ buffer $(\mathrm{pH}$ 3.5) and submitted to dialysis by the procedure described previously. It was found, in this case, that the enzyme solution should be colorless and contain more than $5 \%$ of the enzyme protein to perform enzyme crystallization. Crystallization was started after a 2 days' dialysis and completed 3 days later. This type of enzyme crystallization was preferably used for the large 
Table I. Over-all Purification of the Acid Protease

\begin{tabular}{|c|c|c|c|c|}
\hline Procedure & $\begin{array}{l}\text { Total } \\
\text { activity } \\
\text { (units) }\end{array}$ & $\begin{array}{c}\text { Specific } \\
\text { activity } \\
\text { (units/mg) }\end{array}$ & $\begin{array}{c}\text { Purifica- } \\
\text { tion } \\
\text { (fold) }\end{array}$ & $\begin{array}{c}\text { Recovery } \\
(\%)\end{array}$ \\
\hline & $\ldots 67,800$ & 0.088 & 1 & 100 \\
\hline
\end{tabular}

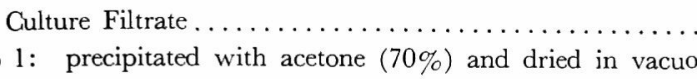

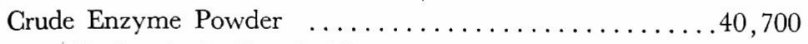

Step 2: dissolve in buffer $(0.02 \mathrm{M}, \mathrm{pH} 3.5)$ and subjected to column chromatography (Duolite CS-101)

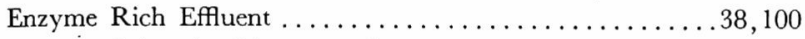

Step 3: precipitated with ammonium sulfate $(0.4$ to 0.8 saturation)

Ammonium Sulfate Fraction

Step 4: dissolve in buffer $(0.02 \mathrm{M}, \mathrm{pH} 3.5)$ and dialyzed against the buffer

Dialyzed Enzyme Solution .................23,200

0.177

2

60

Step 5: passed through a resin bed (Duolite A-7) Decoloriged Enzyme Solution

Step 6: treated with cold acetone $(20 \%)$ and left standing in the cold

Enzyme Crystals..................... 5,570

27.5

8.2

* Step 5 can be omitted if the ammonium sulfate fraction is substantially colorless.

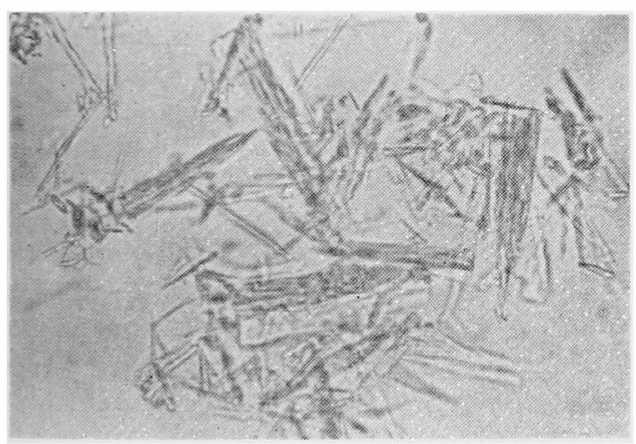

FIG. 3. Microphotograph of Crystalline Acid protease. $(\times 400)$

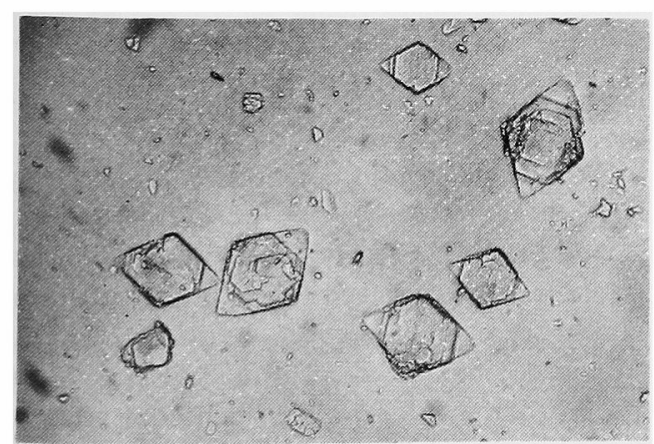

FIG. 4. Microphotograph of Crystalline Acid protease. $(\times 400)$ scale preparation of the acid protease in crystalline form with about $10 \%$ recovery of the original activity.

In the preparation of a bacterial amylase, it has already been found that the crystallization was accomplished by dialyzing the enzyme solution in the presence of calcium ion. In contrast, however, the acid protease crystallization proceeded without the presence of any cations.

The over-all procedure for preparing the crystalline acid protease from the culture filtrate is summarized in Table I, where it is indicated that the enzyme was purified approximately 30 fold with about $8 \%$ recovery of the original activity. Microscopic observations of the crystalline enzyme so obtained, as shown in Figs. 3 and 4 , revealed needle or platelet form crystals.

Acknowledgement. We wish to express our sincere gratitude to Dr. S. Tatsuoka, Dr. R. Takeda, Dr. M. Isono of this laboratories and Mr. Y. Ishida of the Fermentation Department of the Technical Center of this industries, for their encouragements throughout the present work.

We also wish to thank Dr. T. Hasegawa for the supply of the strains used in this work. 